\title{
The Negative Effects of Social and Educational Policy Changes on the Religious Mission of Catholic Secondary Schooling in Zambia's Southern Province: A Historical Analytical Perspective from 1964 to Date
}

\author{
Dr. Farrelli Hambulo \\ Department of Religious Studies, University of Zambia
}

Mrs. Mwansa Mukalula Kalumbi

Department of Educational Administration and Policy Studies, University of Zambia

\begin{abstract}
From its inception in Zambia in the 1890s, the Catholic Church has always made a tremendous contribution to Zambia's educational enterprise thereby contributing greatly to national development at various levels. However, educational provision in general and Catholic educational provision in particular has always been affected positively or negatively by various factors in the Zambian setting over the years since the inception of Western education by the Catholic Church in the 1890s. A few existing scholars of Catholic education in Zambia have highlighted various reasons showing both negative and positive effects of changes at the social and educational levels on Catholic educational provision over the years in the Zambian setting. This particular article provides a unique engagement particularly with the negative effects of 'social' and 'educational policy' changes on the 'religious mission' of Catholic secondary schooling in Zambia's Southern Province. The article provides a historical analytical perspective of this aspect from Zambia's independence (1964) to date. Any engagement with the primary purpose or the 'religious mission' of such schools entails an inevitable focus on Religious Education (RE), since the subject is the engine for such a mission within Catholic school contexts worldwide. The article's overarching argument is that some aspects of 'social' and 'educational policy' changes experienced in Zambia since independence have negatively affected RE as a curriculum subject specifically in Catholic secondary schools in Zambia's Southern Province to an extent of rendering the subject almost a blatant failure vis-à-vis its 'religious mission' or 'religious catechetical message' within the school contexts.
\end{abstract}

Keywords: Catechetical; Catholic church; Catholic education, Change; Effect; Education; Mission; Policy; Religious; Social

\section{INTRODUCTION}

The Catholic Church is one of the oldest Churches in Zambia. It was introduced in Northern Zambia in the 1890s by the White Fathers and in Southern Zambia in 1905 by the Jesuits.This was long before Zambia's attainment of political independence in 1964. After its establishment in two provinces of Zambia, the Catholic Church needed to devise a strategy for conversion of the natives to Catholic Christianity in the two areas. The provision of Western education through the school was used as a strategy to convert the natives to Catholic Christianity (Carmody 2004; O'Brien, 2006).

Being one of the first to provide Western education to the natives in Northern and Southern Zambia and much later in all parts of Zambia, Catholic education enjoyed much success owing to its link to upward social mobility in the then Northern Rhodesian society (Snelson, 1974; Carmody, 2004; O'Brien, 2006). A close assessment of the historical context of educational provision in Zambia reveals that, the provision of Catholic education passed through three major stages namely; education under the British South Africa Company (1891-1924), education under the British colonial government (1924-1964) and education after Zambia's attainment of political independence in 1964 (1964 to date) (Carmody, 2002:796). In addition to the enhancement of upward social mobility of the natives, Catholic education was also very attractive to the natives because it was of high quality compared to what was offered by the colonial governments throughout the three major stages of educational provision in Northern Rhodesia highlighted above. The inclusion of a religious aspect in 


\section{Dr. Farrelli Hambulo \& Mrs. Mwansa Mukalula Kalumbi}

the curriculum of Catholic schools has always been a significant aspect of Catholic educational provision not only in Zambia but globally. This aspect was and is still pivotal to Catholic educational provision at all levels (Miller, 2006; Conference for Major Religious Superiors, 2004; Vatican Congregation for Catholic Education, 1988). Therefore, the inclusion of Religious Instruction or Religious Education also attracted many natives to Catholic schools throughout the three stages of educational provision in Zambia. Probably, this attraction could be explained by the sentiments of an African religious philosopher and theologian John Mbiti (1991) when he argues that Africans are notoriously religious by nature owing to the richness of their African religious heritage.

In line with the aforementioned, it can be stated that from the inception of Catholic education in Zambia, among other things, the enhancement of upward social mobility, provision of high quality education and the centrality of a religious aspect in the Catholic school curriculum has formed part of the identity of Catholic education. As pointed out earlier, the inclusion of a religious aspect in all forms of Catholic schooling is crucial as it qualifiesCatholic schools as extensions or indeed significant wings of the institutional Catholic Church with the primary purpose of enhancing their 'religious mission' or conversion of non-Catholics to Catholicism (Guillon, 1975:200). Hence, from ancient times, the Catholic Church has used Catholic schools as tools for its evangelistic mission through the inclusion of a viable Religious Instruction (RI) or Religious Education (RE) programme in the schools' curriculum (Guillon, 1975;Grace, 2006; Miller, 2006; Kabwe, 2010; Chisempere, 1993).

However, over the years since independence (1964), Catholic schools have not remained static in Zambia. This is because the face of Catholic schooling has been changing gradually from 1964 to date. It can be stated that Catholic schooling has been gradually diverging from its own desired philosophy of education as provided in Catholic education policy. At the core of this undesired transformation of Catholic education since 1964 is the changed face of RE as a curriculum subject in the Catholic school curriculumin Zambia. This development is undesired in Catholic circles and to those interested in the welfare of Catholic education because as stated earlier, for evangelical reasons, $\mathrm{RE}$ is the most significant subject in the curriculum of Catholic schools not only in Zambia but globally (Grace, 2002). This diversion from educational practice as directed by Catholic education policy in Catholic schools has led to feelings of dissatisfaction and lamentation on the part of Catholics and others interested in the welfare of Catholic schools especially regarding the current changed face of Catholic schooling (at all levels) in terms of its weakening religious mission in Zambia (Kabwe, 2010; Chisempere, 1993). Scholars in the field of Catholic education in Zambia such as Kabwe (2010), Chisempere (1993), Carmody (2007) and others do acknowledge the changed face of Catholic schooling at different levels since independence and have identified various reasons explaining this status quo.

This article provides a unique contribution to understanding the changed face of Catholic education in Zambia by specifically focusing on the negativeseffects of social and educational policy changes on the 'religious mission' of Catholic secondary schooling in Zambia's Southern Province. The 'religious mission' of Catholic schools is the primary purpose of Catholic educational provision worldwide (Grace, 2006; Miller, 2006). Any focus on the 'religious mission' of such schools worldwide, entails an inevitable preoccupation with REsince it is the engine for the Catholic school's evangelism mission.

\section{Motivation FOR THE STUDY}

As pointed out earlier in the article, a few scholars active in the field of Catholic education in Zambia such as Kabwe (2010), Chisempere (1993) and Carmody (2007) acknowledge that truly the face of Catholic education has been changing over the years since independence (1964). They also acknowledge that this undesired gradual changing of the face of Catholic schooling in the country involves a shift away from educational practice as directed in the philosophy of Catholic education or Catholic education policy. The scholars have also provided various reasons stating whatconstitutes the undesired changes experienced by Catholic schools at all levels since Zambia's independence. The main motivation for writing this article originates from the need to engage with exactly how this undesired gradual change of the face of Catholic schooling has affected the 'religious mission' of particularly Catholic secondary schools in Zambia's Southern Province. This is because it is important to also provide a detailed and concise exposition of how this gradual undesired transformation of Catholic secondary schooling has negatively affected the 'religious mission' of such education 
The Negative Effects of Social and Educational Policy Changes on the Religious Mission of Catholic Secondary Schooling in Zambia's Southern Province: A Historical Analytical Perspective from 1964 to Date

institutions in Zambia's Southern Province. Perceived from Catholic educational policy perspective, it can be stated that, the 'religious mission' of Catholic secondary schools is the primary purpose of such schools worldwide (Grace, 2002; Miller, 2006). As a driving force of this cardinal mission in Catholic schools, RE is actually considered as the most significant subject in the curriculum of Catholic schools (Grace, 2002), hence the importance of focusing on specificallyhow the gradual transformation enhanced by social and educational policy changes over the years in Zambia have negatively affected the subject.

\section{MeThodology}

This study was purely qualitative. The use of qualitative research is justified by the fact that the overall goal of the study was extensive narrative understanding or development of theories (Hamersley and Atkinson, 1983:20). Secondary data sources were utilized to provide answers to research questions relating to the undesired change experienced by RE since Zambia's independence (1964). This was achieved through vigorous reading of relevant books, journal articles, official letters, Unpublished $\mathrm{PhD}$ theses and Zambian national education policy documents. The data obtained through the secondary sources highlighted above formed part of the data obtained for a much larger study entitled 'Catholic secondary education and identity reformation in Zambia's Southern Province'. However, the current data explains the negative effects of social and educational policy changes on the primary purpose (the religious mission) of Catholic secondary schools in Zambia's Southern Province. Qualitative data fromall secondary sources utilized in the study were analyzed descriptively using thematic categorization procedures(Mayring, 2000:5).

\section{LITERATURE REVIEW}

\subsection{The Importance of RE to the 'Catholic School Ethos'}

According to Castriota (1990:3), in simple terms, 'school ethos' "defines and displays the core beliefs of the school and is closely linked to its value system". Therefore, all the core beliefs and values of a school combine to define its school ethos.

\subsubsection{RE and Promotion of Christian Anthropology}

RE is a very significant curriculum subject in Catholic schools worldwide (Miller, 2006; Grace 2002). One of the reasons for this is because of the need for the promotion of the much desired 'Christian Anthropology' within Catholic school contexts. At the core of this Christian anthropology is the centrality of Christ in the school ideology (Miller, 2006;Congregation for Catholic Education, 2009). This is because taking center stage in the doctrine of the Catholic Church is the aspect of placing high regard to the Gospel of Jesus Christ. Associated with this aspect of the doctrine of the Catholic Church is the important teaching and belief that Jesus Christ is the key to salvation because through him, people can be led to God. A Catholic school is always based on a Christian anthropology. One that is not grounded in such cannot be called a Catholic school. Therefore, this implies that, a Christian anthropology is the basis upon which all Catholic schools are founded. In terms of describing the vision of a Christian anthropology in Catholic educational philosophy, it can be stated that in addition to the full human development of the learners, Catholic schools also propose Christ, Incarnate Son of God and perfect Man, as both model and means; to imitate him is, for all men and women, the inexhaustible source of personal and communal perfection (Miller, 2006:3).

\subsubsection{The Role of RE in Catholic Evangelism}

As a curriculum subject in Catholic schools worldwide, RE has a pivotal role in Catholic evangelism. Commenting on the importance of the contribution of the Catholic school to the church's evangelizing mission, Haldane (1996:133) suggests that "the primary function of a Catholic school is to provide forms of education through which the essential doctrines and devotions of Catholicism are transmitted and the provision of this education is a non-negotiable duty". This is because the Catholic school always forms part of a local church in any context and shares in its life through the transmission of the essential doctrines and devotions of Catholicism to the learners within its school setting.It is through a viable RE programme in the school's curriculum that essential Catholic doctrines and devotions are transmitted to the learners in Catholic school contexts. 


\section{Dr. Farrelli Hambulo \& Mrs. Mwansa Mukalula Kalumbi}

\subsubsection{The Role of RE in the Holistic Development of Learners}

In Catholic schools normally various skills and academic competences are inculcated in the learners. However, such schools cannot only be places where various skills and academic competences meant to support the competitive marketplace in the corporate world are inculcated in the learners. Rather, the Catholic school is much more than this as it "sets out to be a school for the human person and of human persons" (Miller, 2006:3). This implies the aspect of inculcating spiritual or religious development in the learners in order to enhance their balanced development or holistic development. This involves the use of RE in the curriculum of Catholic schools in order to enhance the harmonious development of the physical, moral, intellectual and spiritual dimensions of children and young people in society. It is important to mention that at the core of this holistic formation of children and young people "is a specific focus on Jesus Christ since in him, all human values find their fulfillment and unity" (Vatican Congregation for Catholic Education, 1988:21; Davies, 1999:56). The issue of the holistic development of the learners within Catholic school contexts is so important that, as pointed out already, Catholic education has a specific mission of enhancing the total-formation of the human person (Vatican Congregation for Catholic Education, 1988; Vatican Letter on Catholic Education, 2006; Konstant, 1996; Grace, 2002). Therefore, such schoolsfully guarantee and support the harmonious development of children and young people leading to the achievement of the much desired total-formation of the human person in Catholic circles globally (Sullivan, 2004:16). It is because of the sentiments highlighted above that Miller (2006:3) posits that in Catholic schools, RE comes in to ensure a balanced development of the learners.

\subsubsection{Religion as the Center and Fulcrum of Catholic Education}

In Catholic circles, the importance of a religious aspect in the curriculum of Catholic schools globally is further justified by the Catholic understanding that "Christ is not an afterthought or an add-on to Catholic educational philosophy. This is because Christ is the center and fulcrum of the entire enterprise of Catholic education and the light enlightening every child that comes into a Catholic school" (Miller, 2006:3). In the same vein, it can be stated that Jesus Christ inspires and guides Catholic education and is a model offered to the learners in Catholic schools for emulation. It is for this reason that Jesus Christ takes center stage in all fundamental aspects of the Catholic school such as; "the different dimensions of its life and activity, its philosophy of education, its curriculum, its community, its selection of teachers and even its physical environment" (Miller, 2006:4). Based on these aspects, it can be stated that Jesus Christ ennobles Catholic education and also gives it meaning to human life.

\subsubsection{RE as the Basis for the Production of Good Citizens for the Next World}

Catholic schools are inspired by a supernatural vision. This is because apart from production of good citizens of the current world through the Gospel of Jesus Christ, through the teaching of RE, suchschools also have a duty to produce good citizens for the next world. This can be achieved through RE specifically by helping the learners to fulfill their goal of becoming saints (Miller, 2006; Vatican Letter on Catholic Education, 2009; Vatican Congregation for Catholic Education, 1988). Therefore, Catholic education needs to help man fulfill his transcendent destiny, through its obligation to enable every child entrusted in its care to fix his or her eyes on heaven because in Catholic circles, the attainment of it is everyman's ultimate goal. It is for this reason that Miller (2006:5) states that RE should not just be meant to improve worldly success among the learners but should also focus on preparing children for the world to come or the afterlife.

\subsubsection{RE as the Basis for the Achievement of the Catholic School Mission Statement}

The Catholic school 'mission statement' should be recognized and counted among important features of Catholic education. All Catholic schools have mission statements. According to Grace (1998:48), "mission statements were being used in Catholic educational culture long before the concept was appropriated and generalized in modern institutional practice". This implies that mission statements are not a recent phenomenon in Catholic education. Grace (2002:48) further posits that "mission statements have many Catholic virtues and they constitute a principled and comprehensive charter of what a school claims to be, that is, its distinctive educational, spiritual, moral and social purposes". The Catholic school mission statement vividly indicates what should constitute a Catholic school in terms of virtues as well as its educational, spiritual, moral and social purposes.It is important to mention here that all these aspects are firmly grounded in a viable RE programme hence pointing to the centrality of this programme in the curriculum of Catholic schools. 
The Negative Effects of Social and Educational Policy Changes on the Religious Mission of Catholic Secondary Schooling in Zambia's Southern Province: A Historical Analytical Perspective from 1964 to Date

\subsubsection{RE is Central to the Cultural Formation of Learners}

$\mathrm{RE}$ is a mandatory subject in Catholic schools which all students should take up in the school curriculum (Congregation for Catholic Education, 2009). Removing RE from the Catholic school curriculum would mean depriving the learners an essential element of their formation and personal development. Through formation and personal development, the learners obtain an important balance between culture and faith. In fact, it is important to state that the development of the religious dimension in the learners is central to cultural formation (Astley, 1994). Moreover, this also contributes to the overall formation of the person making it possible for the transformation of knowledge into wisdom of life (Astley, 1994; Hambulo, 2007).

\section{Presentation of Findings}

The intention of this study was to give an exposition of the negative effects of social and educational policy changes on the religious mission of Catholic secondary schooling in Zambia's Southern Province. It did this by providing a historical analytical perspective from 1964 to date. Therefore, in this regard, the following research findings were revealed by the study:

a) The transition of the Zambian society from a predominantly Christian society to a multi-faith society following Zambia's attainment of political independence in 1964 led to an urgent need to unite the Zambian society and the most appropriate way for government to achieve this was through the education system hence among the various subjects in the national education curriculum in Zambia, RE was perceived as a natural option to achieve this significant national agenda. Perceived through Catholic lenses, the use of RE to achieve this national agenda shortly after Zambia's independence negatively affected the religious mission of Catholic schools at all levels in Zambia's education system.

b) After Zambia's attainment of political independence in 1964, government emphasis on an educational programme based on the modernization framework meant an almost exclusive focus on the natural sciences and a cognitive emphasis at the expense of a religious emphasis in Zambia's education sector.

c) The development of a multi-faith RE programmeby the Ministry of Education (MoE) in Zambia's education sector after Zambia's attainment of political independence in 1964 meant a blow to thereligious mission of Catholic schools in the Southern Province.

d) The shift by RE from a confessional or catechetical subject to an educational subject with educational principles in 1972 in Zambia's education sector was a major blow to the religious mission of Catholic schools in the Southern Province.

\section{DISCUSSION OF FINDINGS}

\section{a) Transition of the Zambian Society from a Predominantly Christian Society to a Multi-Faith Society}

One of the major aspects forming part of the dawning of political independence for Zambia in 1964 was the inevitable aspect of social change. This is because by nature, societies are not static butdynamic. Therefore, Zambia's society became increasingly multi-ethnic after independence (Larmer, et al., 2014; Colson, 1999:69). This meant that like never before, Zambia's society consisted of Hindus, Muslims and Zambian traditionalists living side by side at the same time. As such, at the time, government was concerned to ensure the unity of all ethnic groups in Zambia (Lamer, et al., 2014:903; Colson, 1999:69). Since government saw the education system as one of the best avenues to achieve this important national agenda, it directed the Ministry of Education (MoE) to among other things direct the subjects of instruction and syllabuses in all schools in the country (GRZ, 1966). This directive was achieved through the educational proposals and recommendations contained in the 1977 national education policy document entitled 'Educational policy Reform: Proposals and Recommendations'. It is this document which for the first time in Zambia, directed the use of multifaith syllabuses of RE in all schools including Catholic schools in the country (GRZ, 1977). This development was good from a national perspective as it enhanced the achievement of the national agenda of uniting the different ethnic groups of Zambia through the education sector. However, from a Catholic educational perspective, it can be stated that this development was not that good because it 


\section{Dr. Farrelli Hambulo \& Mrs. Mwansa Mukalula Kalumbi}

weakened the 'religious mission' of the schools as the teaching of religion through RE in the schools was no longer predominantly Christian. This meant that the confessional duty assigned to RE in Catholic schools globally (Miller, 1996; Grace, 2006) was no longer that effective in Zambia as there was also need to grant attention to other religious traditions in the teaching of RE in Catholic schools. Therefore, the need to unite the country at independence meant the loss of a total Christian focus in the teaching of religion in Catholic secondary schools as there was also the need to focus of other religious traditions from Zambia's social context. In a way, the inclusion of other religious traditions in RE diluted the Christian message in the Catholic secondary school curriculum thereby weakening the 'religious mission' of such schools in Zambia's Southern Province.

\section{b) The Modernization Framework Versus a Religious Emphasis in Zambia's Education Sector}

As the case for all newly independent states, Zambia's attainment of political independence in 1964 meant a lot of work for the newly independent state. This included the urgent need for Zambia to modernize especially in the area of education because shortly after independence, most Zambians were not well educated to help the new nation to develop (Carmody, 2004:25). This urgent need for Zambia to modernize shortly after attainment of political independence was firmly grounded in the centrality of the modernization framework as a reliable model for social-economic development in the 1950s and 60s (Walters, 1981; Schultz, 1961; Rostow, 1962). It is also important to mention that the premise for the modernization framework was that investment in human capital led to national development.

In what should be perceived as the post-Vatican II, global stance grounded in a spirit of openness and mutual cooperation adopted by the Catholic Church from 1965 to date, the church cooperated with the Zambian government in its education programme based on the modernization framework. This was meant to increase the levels of educational capacity in Zambia for the achievement of national development (Carmody, 2004:25). As such, Zambia's first major national education policy document entitled 'Education Reform:Proposals and Recommendations which was published in 1977 was a product of an earlier long and comprehensive educational reform programme embarked upon by government known as 'Education for development'. One of the main aims of the 1977 national education policy document was to provide opportunities for each person to contribute the economic and social development of Zambia (GRZ, 1977). In the same vein, Zambia's 1996 national education policy document entitled 'Educating Our Future' also places very high regard to the aspect of 'education for national development' (GRZ, 1996). This current major education policy document in Zambia affirms its commitment to the 'Education for development' national programme when it strongly reaffirms the important role education plays in human resource development and that it is the basis of all other development (GRZ, 1996).

In line with the aforementioned, it can be stated that, although the aspect of 'Education for development' may seem very progressive at national level in Zambia, at Catholic educational level, this aspect has weakened the 'religious mission' of Catholic schools in general and Catholic secondary schools in Zambia's Southern Province in particular. This is because from its inception, the 'Education for development' aspect which is firmly grounded in the modernization framework, has led to an almost exclusive focus on the natural sciences and a cognitive emphasis in education provision at the expense of the religious or spiritual emphasis which is deemed more important in Catholic educational provision not only in Zambia but worldwide (Lamer, et al. 2014:908). The effects of the modernization paradigm of the 1950s and 60s in Zambia's schools are still evident today especially in Catholic secondary schools in Zambia's Southern Province as emphasis is still placed on natural sciences in the school curriculum mostly for the sake of upward social mobility purposes on the part of the learners as such an emphasis helps them get prestigious jobs in the Zambian society in different academic fields. This is done at the expense of instilling a religious aspect through RE in the learners. As a result, the 'religious mission' of such schools is rendered almost a blatant failure in Zambia's Southern Province.

\section{c) The Development of a Multi-Faith RE Programme by the MoE}

Throughout the three major stages of Zambia's educational history namely; education under the British South Africa Company (1891-1924), education under the British colonial government (19241964) and education after Zambia's attainment of political independence in 1964 (1964 to date), RE was one of the most important curriculum subjects in the schools. Moreover, throughout the three 
stages highlighted above, Religious Instruction (RI) or RE was predominantly Christian in all schools. In other words, the teaching of religion in schools meant the inculcation of Christian values in the learners as Western education was firmly grounded in Christian values and principles of civilization (O'Brien, 2006; Carmody, 2004; Snelson, 1974).As such, in the first two stages of Zambia educational history stretching from 1890 to 1963 , RE was strategically positioned in the school curriculum specifically for the religious catechetical purpose or the 'religious mission' of Catholic schools. However,in the years after Zambia's attainment of political independence (1964 onwards), government through the MoE among other things beganto control and monitor the subjects of instruction and syllabuses in the country and RE was not an exception to this development (GRZ, 1966). As indicated earlier, for the sake of achieving the national agenda of uniting Zambia's multiethnic society in the years following independence, as part of the newly acquired privilege for control of the subjects of instruction and syllabuses, the MoE introduced a multi-faith RE programme in Zambia's education sector. This meant that RE was no longer centered on Christianity alone but also included other religious beliefs from Zambia's social context. Therefore, from this time onwards, to be religiously educated in Zambian schools also meant being familiar with Hinduism, Islam and Traditional Zambian Beliefs (Curriculum Development Center, 1983:3). This development contributed to the weakening of the 'religious mission' particularly in Catholic secondary schools in Zambia's Southern Province. In addition to the inclusion of religious traditions other than Christianity in the RE syllabuses was also the need for professionalism in the teaching of RE in the Zambian education sector. This partly meant the avoidance of indoctrinating learners into upholding any particular religious belief system in the teaching of religion in the schools as the issue of deciding on which religious beliefs to uphold should be left to the autonomous decisions of the learners themselves. The blow to the 'religious mission' of Catholic secondary schools in Zambia's Southern Province here was that from 1977 onwards (After publication of Zambia's first national education policy), RE was no longer dominated by Christian beliefs. Moreover, an additional blow to the 'religious mission' of Catholic secondary schools was the professional teaching of the subject where the new reality was that the choice of which religious beliefs to uphold in RE lessons was left entirely to the learners and not the teachers or the schools. After these developments, the chance of the learners upholding religious traditions other than Christianity in RE lessons in the schools was increased by the introduction of a multi-faith RE programme in Zambia's education sector by the MoE following the attainment of Zambia's independence in 1964.

\section{d) The Shift by RE from a Confessional or Catechetical Subject to an Educational Subject}

A close inspection of the origin and development of RE as a curriculum subject in Zambia reveals that from the inception of Western education in the 1890s in Northern Rhodesia, RE was always intendedto be a confessional or catechetical subject by different Christian missionary bodies in the three major stages of educational provision in the country. This entails that RE was a major tool for the achievement of the missionaries' 'religious mission' in their respective schools. In line with this, it is clear that for the Catholic Church, the school was used as a tool for its evangelistic mission or its religious mission through RE (Guillon, 1975:200). Therefore, Religious Instruction (RI) was utilized to achieve the 'religious mission' of the schools by various missionary groups before 1972 in Zambia. According to Simuchimba (2005) there was a major change in Zambia's education sector in 1972 as RI was replaced by RE as a curriculum subject in Catholic schools. The meant that from a confessional or religious catechetical subject, with the aim of nurturing the learners and converting them to Catholicism in the years before 1972, the subject transformed into an educational subject with educational principles in 1972. From 1972 onwards, the aims of RE as a curriculum subject in Zambia's education system changed tremendously as they became more educational in nature. For instance, as a curriculum subject, RE needs to provide opportunities to each person to develop emotionally, morally, spiritually, socially and politically so as to be increasingly able to cope with life's problems (GRZ, 1977). Moreover, another educational aim of RE at Grade 9 level stated in Zambia's current national educational policy document published in 1996 is that "the learners should attain a suitable level of competence in knowledge and understanding of spiritual, religious and moral values and appreciation of the traditions within which they have developed" (GRZ, 1996). Based on the above sentiments, it can be stated that a close scrutiny of the aim of RI and the subsequent aims of $\mathrm{RE}$ as a curriculum subject in Catholic secondary schools in Zambia's Southern Province portrays a 
significant shift from 1972 onwards. This shift from RI to RE in Catholic secondary schools in the Southern Province is a blow to the 'religious mission' of the schools. It is a blow to the 'religious mission' of such schools because it represents a diversion from Catholic education policy regarding the main purpose (religious mission) of Catholic schooling not only in Zambia but worldwide. This is because, the shift is from a religious catechetical curriculum subject grounded in Catholic faith nurturing in the learners to an educational curriculum subject grounded in educational principles. In line with the shift of RI to RE in Catholic schools highlighted above, it is vital to express the lamentation expressed in Catholic circles and also shared by Berman (1975: xi) and Arthur (1995:231), when they argue that the role of the Catholic Church school had changed tremendously to an extent where the rigors of academic preparation are placed above its religious catechetical message.

\section{Conclusion}

As a conclusion, it can be stated that perceived from a Catholic educational policy perspective, the main role of Catholic schools is to act as dependable and reliable extensions of the institutional Catholic Church. This entails that such schools should always succeed in their primary purpose of promoting their 'religious mission' by converting more non-Catholics to Catholicism (Guillon, 1975). The main avenue for the dissemination of the religious catechetical messageto the learners is through a viable RE programme in the schools worldwide (Grace, 2006; Miller, 2006).

However, as indicated above, the role of a Catholic secondary school particularly in Zambia's Southern Province has changed tremendously leading to the increased weakening of its 'religious message' over the years since Zambia's independence in 1964. Among the various causes for this outcome are the negative effects of changes at the social and educational policy levels on the 'religious mission' of Catholic schools, particularly Catholic secondary schools in Zambia's Southern Province since independence.

Among the negative effects of changes at the social and educational policy levels are; the transition of the Zambian society from a predominantly Christian society to a multi-faith society at independence, the effect of the modernization framework on a religious emphasis in Zambia's education sector shortly after independence, the introduction of a multi-faith RE programme by the MoE after independence and finally the shift by RI to RE in 1972 signifying a transition from a confessional subject to an educational subject. Together, the negative effects of the changes at the two levels highlighted above have tremendously changed the role of Catholic secondary schools in Zambia's Southern Province to an extent were their 'religious mission' has been rendered almost a blatant failure.

\section{REFERENCES}

[1] Arthur, J. (1995). The Ebbing Tide: Policy and Principles of Catholic Education. Leominster: Gracewing Publications.

[2] Astley, J. (1994). The Philosophy of Christian Religious Education. Alabama: Religious Education Press.

[3] Berman, E. (1975). African Reactions to Mission Education. New York: Teacher College Press

[4] Carmody, B.P. (2004). The Evolution of Education in Zambia. Lusaka: Book World Publishers.

[5] Carmody, B.P. (2002).The Politics of Education in Zambia 1891-1964. Journal of Church and State, 44(4):775-804.

[6] Carmody, B.P. (2007). Catholic Church and State Relations in Zambian Education: A Contemporary Analysis. In International Handbook of Catholic Education Part II edited by Grace, G.R. and O'Keefe, J., 543-562. Dortrecht: Springer.

[7] Castriota, D. (1990). What Constitutes a Good School? London: University of Wisconsin Press.

[8] Chisempere, J. (1993). Dealing with Secularism and Materialism in a Catholic School. Jesuit Center for Theological Reflection Bulletin, 16(2):14 - 16.

[9] Conference of Major Religious Superiors (2004). The Catholic School in Contemporary Society. Dublin: CMRS.

[10] Congregation for Catholic Education (2009). Letter to the Presidents of the Bishops' Conference on Religious Education in Schools, $8^{\text {th }}$ September, Vatican Archives, Vatican City. 
The Negative Effects of Social and Educational Policy Changes on the Religious Mission of Catholic Secondary Schooling in Zambia's Southern Province: A Historical Analytical Perspective from 1964 to Date

[11] Colson, E. (1999). The Bantu Botatwe: Changing Political Definitions in Southern Zambia. In The Politics of Cultural Performance edited by Parkin, D., 61-80. Oxford: Berghahn Books.

[12] Curriculum Development Centre (1983). Zambia Basic Education Course: Moral and Spiritual Education Syllabus. Lusaka: CDC.

[13] Davies, R. (1999). Can there be a Catholic Curriculum? In: Conroy, J. (ed.) Catholic Education: Inside Out/Outside In. Dublin: Lindisfarne Books, pp. 54-71.

[14] Grace, G. (2002). Catholic Schools: Mission, Markets and Morality. London: RoutledgeFalmer.

[15] Grace, G. (1998). Realising the Mission: Catholic Approaches to School Effectiveness. In: Slee, R., Weiner, G., and Tomlinson, S. (eds.) School Effectiveness for Whom? London: Falmer Press, pp. 45-59.

[16] Guillon, M.J. (1975). Outside the Church no Salvation. In Encyclopaedia of Theology, e dited by Rahner, K. 200-201. New York: Seabury.

[17] Haldane, J. (1996). Catholic Education and Catholic Identity. In: McLaughlin, T., and O'Keeffe, B. (eds.) The Contemporary Catholic School. London: Falmer, pp.126-135.

[18] Hambulo, F. M. (2007). Why should Religious Education form part of the National Education Curriculum in Zambia. University of Dublin, Trinity College: Unpublished Masters' Thesis.

[19] Hammersley, M. \& Atkinson, P. (1983). Ethnography, Principles in Practice. New York: Tavistock.

[20] Kabwe, F. (2010). Can Catholic Institutions Reclaim their identity? Jesuit Center for Theological Reflection Bulletin, 58(4):11 - 15.

[21] Konstant, D. (1996). The Distinctiveness of Catholic Education. London: Burns \& Oates.

[22] Larmer, M., Hinfelaar, B. J., Phiri, J., Schumacher, L. and Szeftel, M. (2014). Introduction: Narratives of Nationhood. Journal of Southern African Studies. 40 (5): 895-905.

[23] Simuchimba, M. (2005). Religious Education in Zambia, 1890-2000 and Beyond. Unpublished $\mathrm{PhD}$ Dissertation. University of South Africa.

[24] Sullivan, J. (2002). Catholic Education Distinctive and Inclusive. London: Kluwer.

[25] Mayring, p. (2000). Qualitative Content Analysis. Weinheim: Deutscher Studien Verlag.

[26] GRZ (1966). Education Act of 1966. Lusaka. Government Printers.

[27] GRZ (1996). Educating Our Future: National Policy on Education. Lusaka: Government Printers.

[28] GRZ (1977). Educational Reform: Proposals and Recommendations. Lusaka: Government Printers.

[29] Mbiti, J.S. (1991). Introduction to African Religion 2nd Ed. Dar es Salaam: East African Educational Publishers Ltd.

[30] Miller, J.M. (2006). The Holy See's Teaching on Catholic Schools. Atlanta: Sophia Institute Press.

[31] O'Brien, D. (2006). The Struggle for Control of Education in Zambia. Lampeter: Edwin Mullen Press.

[32] Schultz, T. (1961). Investment in Human Capital. American Economic Review. LI: 1-17.

[33] Snelson, P. D. (1974). Educational Development in Northern Rhodesia 1888 - 1945. Lusaka: Neczam.

[34] Rostow, W.W. (1962). Stages of Economic Growth. London: Cambridge University Press.

[35] Vatican Congregation for Catholic Education (1988). Catholic Education. Vatican City: RFC Press.

[36] Vatican Congregation for Catholic Education (1988). The Religious Dimension of Education in a Catholic School. Dublin: Veritas.

[37] Vatican on Catholic Education (2006). Letter on Ensuring Excellence in Catholic Education, 5th October, Vatican Archives, Vatican City. 
[38] Vatican on Catholic Education (2009). Letter on Catholic Education, $18^{\text {th }}$ May, Vatican Archives, Vatican City.

[39] Walters, B. (1981). Education Change and National Economic Development. Harvard Education Review. 51 (1): 94-106.

\section{AUTHORS' BIOGRAPHY}

Dr.Farrelli Hambulo, is a lecturer in the department of Religious Studies at the University of Zambia and holds a Masters degree in Religious Studies and a Ph D in Philosophy of Education. He has authored scholarly articles in Religious Studies, Philosophy of Education and General Education in local and international journals. He is also involved in collaborative research projects locally and internationally. His current research interests are in; Catholic education, Educational Policy Studies as well as the nature, role and place of 'religion' in Zambia's national education curriculum.

Mwansa Mukalula-Kalumbi, is currently a Lecturer and a Special Research Fellow in Educational Policy in the Department of Educational Administration and Policy Studies at the University of Zambia. She holds a Bachelor of Arts with Education degree and a Master of Educational Administration degree from the University of Zambia. She has authored articles on educational policy and HIV/AIDS, education and legal issues. Her research interests include: Policy Issues in Education, HIV and AIDS and Early Childhood Education and Legal Issues in Education. 